Rui Lu, Minghai Wei, Wenjing Li

\title{
Managerial Power, Perquisite Consumption and the Efficiency of Property Right System: Evidence from Chinese Listed Companies
}

(C) Higher Education Press and Springer-Verlag 2010

\begin{abstract}
This research uses data of Chinese listed companies during 20012004 to test the effects of managerial power on perquisite consumption and firm performance from the perspectives of CEO duality, ownership dispersion and long-term tenure of top executives. Results show that companies with higher managerial power tend to incur higher perquisite consumption, while their performance does not improve accordingly. Moreover, perquisite consumption fails to offer effective incentives to managers, and non-state-controlled listed companies have greater managerial power, higher perquisite consumption, and worse performance than that of their state-controlled peers. Results also show that managerial power is an important factor influencing compensation incentive.
\end{abstract}

Keywords managerial power, perquisite consumption, performance, property right

\section{Introduction}

Recent studies on compensation incentives have shown that corporate managers Translated from Nankai Guanli Pinglun 南开管理评论 (Nankai Business Review), 2008, (5): 85-92, 112

Rui Lu $(\bowtie)$

Lingnan College, Sun Yat-sen University, Guangzhou 510275, China

E-mail: lurui@mail.sysu.edu.cn

Minghai Wei

School of Business, Sun Yat-sen University, Guangzhou 510275, China

E-mail:mnswmh@mail.sysu.edu.cn

Wenjing Li

Management School, Jinan University, Guangzhou 510632, China

E-mail: zsublue@163.com 
can significantly influence or even determine their own compensation, and that compensation incentives do not necessarily alleviate the prolonged agency problem. There is a possibility that managers might abuse their power to make "good-intentioned" compensation incentive part of the agency problem. Based on prior empirical research, Bebchuk and Fried $(2002,2003,2004)$ formulated two theories concerning executive compensation: the optimal contracting approach and the managerial power approach. In their papers, managerial power usually refers to the influence managers can exert on corporate governance system including decision-making right, superintendence and execution right. Such influence can affect executive compensation contract in managers' own interests. To date, much research on compensation incentives has adopted the optimal contracting approach (Wei, 2000; Li, Sun and Liu, 2005). However, considering the prevalence of insider control problem in China likely due to the "absence of owner" (Fei, 1996) and "single big shareholder" equity structure, it might be appropriate to adopt the managerial power approach to studying the relationship among managerial power, perquisite consumption and efficiency of property right system. In addition, most of the listed Chinese state-owned enterprises (SOEs) submit their executive compensation schemes to the State Assets Administration Committee for approval. During the process of submission and approval, managers in SOEs might utilize their power to tilt compensation schemes in their interests. All of these reasons justify the adoption of the managerial power approach to studying the influence that managers exert on compensation incentives.

Managerial compensation packages mainly consist of monetary compensation, equity incentive, and perquisite consumption. Compared with the former two compensation schemes, perquisite consumption is usually regarded as an implicit compensation, which refers to monetary or other forms of consumption incurred when managers performing their duties and therefore should be covered by their companies. Compared with their Western counterparts, managers in Chinese listed companies, particularly managers in SOEs, are more likely to receive lower monetary compensation and equity incentives. In addition, government supervision on SOE managers is rather loose. All of these make high perquisite consumption an important part of executive compensation. Sometimes, the benefits that Chinese managers receive from perquisite consumption are even greater than their monetary compensation. Therefore, research on perquisite consumption will contribute a great deal to solving the managerial agency problem and help us gain a deeper understanding of compensation incentives in China.

Based on the rationale outlined above, we will examine perquisite consumption in Chinese companies from the standpoint of managerial power. Our study will mainly focus on the following questions: Does managerial power 
influence perquisite consumption in listed companies? If perquisite consumption is significantly enhanced by managerial power, will it bring in better firm performance by providing greater stimulation to the management? Are there any differences in managerial power under different property right arrangements? If the answer is yes, will these differences in managerial power in turn lead to difference in perquisite consumption and firm performance? To answer these questions, this research will explore the dynamic mechanism among managerial power, perquisite consumption, firm performance, and property right system in the following sections.

\section{Literature Review and Hypotheses Development}

\subsection{Literature Review}

\subsubsection{Research on Managerial Power Based on Compensation Contracts}

An important idea underlying the research on managerial power and compensation contracts is that top executives with sufficiently high managerial powers can significantly influence, or even determine the stipulation of their own compensation schemes. Main et al. (1993) found that that some CEOs can strongly control the nomination process of board members. A survey of CEO manipulation over remuneration committee found that outside directors tend to be partial to CEOs rather than be objective evaluators (Main, O'Reily and Wade, 1995). Similarly, it was argued that companies characterized by big board of directors and large percent of CEO-nominated outside directors are more likely to have higher CEO compensation and poorer firm performance (Core, Holthausen and Laker, 1999). Furthermore, managers can utilize their power to establish various optional incentive schemes in their favor (Bebchuk, Fried and Walker, 2002). Cheng (2005) found when a company provides executives with more power, it is more likely to have higher sensitivity between compensation and profit performance and lower sensitivity between compensation and loss performance. Bebchuk and Fried $(2002,2003,2004)$ developed two theories on the determination of executive compensation: the optimal contracting approach and the managerial power approach. The former refers to that shareholders can control the board and design executive compensation arrangement according to the principle of shareholders' interests maximization and the latter denotes that managers have the power to influence their compensation contracts and utilize this power to seek rent, particularly in companies ridden with insider control problem.

In China, studies on the influence of managerial power on compensation incentives are seriously lacking. Prior research has analyzed whether 
compensation contracts are controlled by shareholders or executives (e.g., Yang, $\mathrm{Ke}$ and Ma, 2005; Li et al., 2005). Lu (2007) explored the influence of managerial power on the compensation gap within the executive team. Wang and Wang (2007) studied the influence of managerial power on executive compensation level and the extent of earnings management motivated by compensation. Zhang and Shi (2005) studied the influence managerial power has over executive compensation and the sensitivity between compensation and firm performance from the standpoint of board character. Among these studies, Li et al. (2005) included the variable of perquisite consumption, assuming that managers' monetary compensation and non-monetary compensation have a negative relationship under the shareholders control theory and a positive relationship under the management control theory. However, the logic under their hypothesis is somewhat problematic: Neither high monetary compensation nor non-monetary compensation under the management control theory necessarily means there is a positive relationship between the two compensation means. Besides, in their study, Li et al. focused only on the fact that whether there is phenomenon of managers controlling their compensation contracts among Chinese listed companies, rather than identifying the evidence of the impact of managerial power on executive compensation, or directly studying the influences of managerial power on perquisite consumption and its corresponding consequences.

\subsubsection{Research on Perquisite Consumption}

Western research on perquisite consumption has mostly been conducted from the perspectives of organization theories or corporate governance. As Jensen and Mecking (1976) pointed out, without taking into consideration of government supervision and the other restrictions, managers would increase their non-monetary compensation to achieve utility maximization. In addition, the fewer shares held by the management, the lower the cost of their perquisite consumption, and the more likely for managers to favor non-monetary welfare. Alchian and Demsetz (1972) illuminated the endogenous nature of perquisite consumption from the perspective of information cost. They argued that the cost of opportunism prevention might be higher than its benefit from it. Therefore, for senior managers, permitting staffs to enjoy privilege and perquisite consumption and other privileges are a natural outcome of high information cost. There has been, however, little empirical research on perquisite consumption among Western researchers. Among the small number of researchers that actually did so, Yermack (2005) studied the influencing factors of senior managers' perquisite consumption and the impact of such consumption on market. They found an insignificant relationship between the expense of perquisite consumption and 
senior managers' annual compensations and their shareholding percentage. Rather, their study revealed that perquisite consumption is related to the CEO personality. Moreover, loss in share price further exceeds the amount of perquisite consumption expense once the amount of perquisite consumption is announced. Rajan and Wulf (2006) found empirical evidence showing that perquisite consumption is positively related to managers' work efficiency.

Chinese research on perquisite consumption has mainly focused on SOEs. Fei (1996) and He (1998) argued that SOEs have severe insider control problem caused by loose control of property right, which in turn leads to high perquisite consumption. Chen, Chen and Wan (2005) asserted that perquisite consumption is endogenously originated in compensation governance mechanism. Other domestic researchers (e.g., Zhou, 1997; Zhang, 1998; Huang, 2000) explored perquisite consumption based on the control-right-benefit theory, which assuming that manager incentives can be divided into two parts: monetary benefits and control power benefits. The control power benefits are non-monetary benefits, including power, gratification of self-fulfillment, perquisite consumption as well as other privileges brought in by being the boss and resource allocator. Though it can stimulate managers to work hard for the fulfillment of company goals, control power benefits sometimes might also lead to excessive perquisite consumption, repeated construction, merger obstacles, corruption and other negative outcomes.

Due to the difficulty in data collection in China, there has been little empirical research on perquisite consumption. Among the little domestic research, work by Xia and Li (2004) and Chen et al. (2005) is representative. They studied the influencing factors of perquisite consumption and the impact of perquisite consumption on the relationship between incentive and performance. Xia et al. (2004) found that a higher percentage of shares held by the controlling shareholders lead to lower perquisite consumption in SOEs, while in non-SOEs, there is a positively complementary relationship between perquisite consumption and monetary compensation of the management. They also found, quite counter-institutively, that the perquisite consumption in non-SOEs is higher than that of in SOEs. Empirical evidence collected by Chen et al. (2005) revealed that perquisite consumption in listed companies is mainly influenced by enterprise rent (as denoted by gross margin rate), absolute compensation, and enterprise size. In addition, compensation arrangement in SOEs is negatively related to firm performance due to the lack of incentive efficiency. There is no such a significant relationship between the two in non-SOEs. However, both Xia et al. (2004) and Chen et al. (2005) did not study the influence of managerial power on perquisite consumption in their papers. 


\subsubsection{Research on the Efficiency of Property Right System}

Ever since China's launch of the reform and opening-up policy in 1978, the efficiency of property right system, particularly comparison of efficiency between SOEs and non-SOEs, has drawn increasingly attention from Chinese researchers. Earlier research believed that privatization is a solution to SOEs' severe agency problem and inefficiency (e.g., Chen, 1997; Liu and Li, 2001). Along with development of China's security market, academic attention has been shifted from efficiency comparison to listed company performance. As the number of private listed companies grows steadily in recent years, more researchers have found serious agency problems in these non-SOEs. For example, $\mathrm{Su}$ and $\mathrm{Zhu}$ (2003) revealed that the controlling shareholders in privatecontrolled listed companies have significant entrenchment effect on minor shareholders, leading to poorer firm performance. Xu (2004) found that entrenchment behaviors prevail in private listed companies. Therefore, she asserted that in the context of transitional economy and inefficient market supervision, government supervision plays an active role in preventing controlling shareholders from tunneling. To date, however, there has been hardly any domestic research on the difference in agency costs between SOEs and non-SOEs from the perspective of managerial power and on the impact of managerial power on firm performance.

\subsection{Theoretical Framework and Hypotheses}

The theoretical framework in this paper is shown in Fig.1:

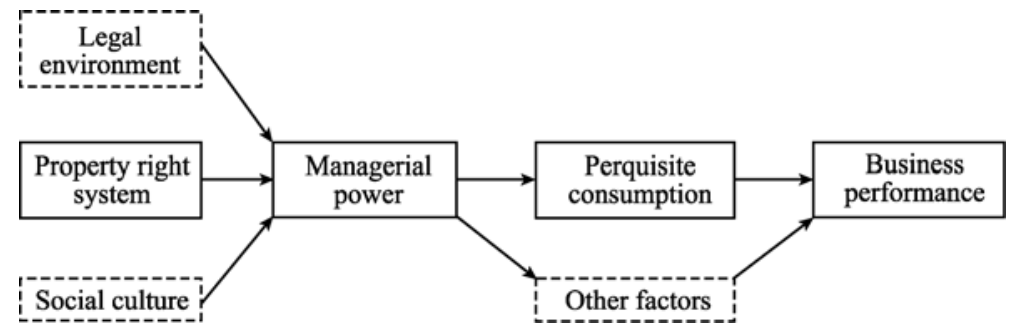

Fig. 1 Theoretical Framework

Based on the managerial power theory, this paper explores the influence of managerial power on perquisite consumption and the influence of perquisite consumption on firm performance. In doing so, we will establish a theoretical framework on the dynamic mechanism of managerial power's influences on perquisite consumption and then on firm performance. To focus exclusively on the impact of managerial power on perquisite consumption and firm performance, we presume in this article that other influencing factor remain unchanged (such 
as legal system, social and cultural factors, etc.).

During the process of China's SOE reform, more decision-making power have been granted to managers, deterioration in perquisite consumption cropped up due to immature restriction and incentive mechanism. As a result, an increase in managerial power does not necessarily lead to firm performance improvement. Perquisite consumption is closely connected to control power: Whoever owns the very power would get access to perquisite consumption. In addition, the incompleteness of compensation contracts also makes it more possible for senior managers to abuse their privileges of perquisite consumption. Generally speaking, the larger the managerial power, the weaker the supervision on senior managers, the more likely perquisite consumption is to be abused. Although there are some other restrictive factors of perquisite consumption, such as the percentage of shares held by the management and legal restrictions, Chinese managers' internalized cost of perquisite consumption is usually low due to the low percentage of shares they held. Therefore, perquisite consumption is more likely to be abused in China with the increase of managerial power, particularly in SOEs where senior managers' monetary compensation is rigorously restricted by the government.

As a rule, top executives with higher managerial power are prone to set up many managerial hierarchies and convert their companies into bureaucratic organizations. Consequently, managers at lower hierarchies would pursue more benefits from the power or rent allocation by means of truckling or bribing the top managerial team (or so-called "shareholders"), rather than endeavor to improve their own performance. We thus argue that expansion of perquisite consumption increases enterprise cost and decreases shareholders' profits, rather than stimulate managers and enhance firm performance.

H1 Companies with larger managerial power are more likely to have higher perquisite consumption, but not significantly better firm performance.

To date, no consensus has been reached in terms of perquisite consumption in SOEs and non-SOEs. As noted above, Xia et al. (2004) did not find any evidence showing that the perquisite consumption in listed SOEs is significantly higher than that of private listed enterprises. When conducting an average testing on the amount of perquisite consumption in both SOEs and non-SOEs, Chen et al. (2005) found little difference between the two types of enterprises in both total amount and average amount of perquisite consumption. Xia et al. (2004), however, found that the average amount of perquisite consumption in non-state owned listed companies is bigger than that of in state-owned listed companies.

The agency problem in Chinese listed companies can be roughly divided into two types: The first is between managers and shareholders (Type I). When the ownership structure is dispersed and supervision over the management team is 
ineffective, managers can take advantage of information asymmetry to their own interests by taking opportunistic behaviors such as slacking, excessive perquisite consumption, grabbing of more control rights, etc. The second type is the agency problem between big and minority shareholders (Type II). When the ownership structure is concentrated, big shareholders can tunnel listed company's cash and profits through related party trade, asset acquisition and other unethical means.

In state-controlled listed companies where managers and shareholders are two independent interest entities, most of the agency problems are Type I problems because shareholders would not tunnel listed companies by means of perquisite consumption; while in private listed companies where managers and big shareholders are usually the same group of people, most of the agency problems are Type II problems because the management in these companies is likely to utilize perquisite consumption as an important tunneling means. By comparison, Type II problem is more severe in China's capital market because shareholder's tunneling behaviors prevail in Chinese listed companies (Liu, He and Wei, 2004; $\mathrm{Li}$, Sun and Wang, 2004). We therefore infer that the level of perquisite consumption in non-state-controlled listed companies is likely to be higher than that of in state-controlled listed companies.

Besides constraints from legal environment, market competition and policy regulation, state-controlled listed companies in China are also supervised by government departments at higher levels. Compared with their peers in state-controlled listed companies, top managers in non-state-controlled companies are more likely to have greater managerial power but less restrictions, making it is easier for them to abuse managerial power and tunnel their enterprises. Thus, we propose $\mathrm{H} 2$ as follows:

H2 Compared with state-controlled listed companies, non-state-controlled listed companies are more likely to have a higher level of perquisite consumption. However, their performances are not likely to be significantly better.

\section{The Sample, Variables and Model}

\subsection{The Sample}

Sampled companies in this paper were A-share listed companies in Shanghai and Shenzhen Stock Exchanges. Data were collected from the annual reports of the sampled companies during 2001-2004. ${ }^{1}$ We deleted the following companies

\footnotetext{
1 The numbers of sampled companies with detailed perquisite consumption data in each year are 322 companies in 2001, 510 companies in 2002, 588 companies in 2003, and 651 companies in 2004. After deletion of invalid samples, the numbers of final samples in state-controlled and non-state-controlled listed companies are 1723 and 1 586, respectively.
} 
from the sample: companies from the financial industry, companies with extreme performance data ( $\pm 1 \%$ companies at both end), companies that issued $\mathrm{B} / \mathrm{H}$ shares in addition to A shares, companies implemented seasoned equity offering, and companies with negative auditor opinions. Data were collected from the databases of CSMAR, CCER, WIND. Statistical software tools including SPSS, Eviews and Excel were adopted in analyzing the data.

\subsection{Variable Selection}

\subsubsection{Perquisite Consumption Measurement}

Both Chen et al. (2005) and Xia et al. (2004) collected perquisite consumption data by referring to the subsidiary account item named "cash flow related to other operating activities" in annual report footnotes. ${ }^{2}$

There are two commonly-adopted measurement methods for perquisite consumption, namely direct and indirect measurement method. The direct method measures perquisite consumption by dividing it into eight categories, namely office expenses, travel fees, hospitality expenses, correspondence expenses, overseas training expenses, board of directors' expenses, and expenses on automobile and conference. The indirect method is to deduct all revealed expenses unrelated to perquisite consumption from the subsidiary account item of "cash flow related to other operating activities." Although both of these two methods are far from being perfect, they are still the most widely adopted methods in calculating perquisite consumption.

In this paper, we adopt two methods similar to the above two approaches for measuring perquisite consumption in Chinese listed companies. The first one is consistent with Chen et al.'s (2005) method. By referring to the subsidiary account of "cash flow related to other operating activities" in sampled companies' annual reports, expenses on the eight categories of perquisite consumption were obtained. The total amount of perquisite consumption was calculated by put the eight expenses together.

The second method is to obtain the amount of perquisite consumption by deducting the controversial administrative expenses, conference expenses, and board of directors' expenses from perquisite consumption data. To better reflect the level of perquisite consumption and to avoid the influence of adopting different scales, the relative value of perquisite consumption variable was used, namely by dividing the amount of perquisite consumption by the prime operating revenue of the year.

${ }^{2}$ Perquisite consumption is reckoned as part of administration expense, it therefore should be disclosed as detailed items in "cash flow related to other operating activities" in a listed company's annual report according to China's disclosure rules for listed companies. 


\subsubsection{Measurement of Managerial Power}

When choosing proper indexes for measuring managerial power, we take into consideration both Western methods (e.g., Bebchuk and Fried, 2004; Cheng, 2005; Hu and Kumar, 2004; Hambrick and Finkelstein, 1995) and the practical conditions in China. Accordingly, three variables were chosen, namely CEO duality, ownership structure dispersion, and long-term tenure. ${ }^{3}$ Among them, the former two reflect managerial power from the dimension of space and the third variable reflects managerial power from the dimension of time (as shown in Table 1).

\subsection{Model Design}

Two models are developed to test the above hypotheses.

$$
\begin{aligned}
& P C_{i t}=\alpha_{0}+\alpha_{1} P O W E R_{i t}+\alpha_{2} P A Y_{i t}+\alpha_{3} A_{S S_{i t}}+\alpha_{4} S_{S O} E_{i t}+\alpha_{5} C E N T R A_{i t} \\
& +\alpha_{6} \text { MRS }_{i t}+\alpha_{7} \text { STAFFGAP }_{i t}+\sum_{i=1}^{20} b_{i} I N D_{i t}+\sum_{02}^{04} c_{i} \text { Year }_{i t}+\varepsilon_{i t} . \\
& R O E_{i t}=\alpha_{0}+\alpha_{1} P O W E R_{i t}+\alpha_{2} P C_{i t}+\alpha_{3} S O E_{i t}+\alpha_{4} A S S_{i t} \\
& +\alpha_{5} P A Y_{i t}+\sum_{i=1}^{20} b_{i} I N D_{i t}+\varepsilon_{i t} .
\end{aligned}
$$

In Model (1), $P C$ stands for perquisite consumption, and explanatory variables are POWER and SOE. As hypothesized, the expected sign of coefficient for $P O W E R$ and $S O E$ should be significantly positive and negative, respectively. Controlled variables include executive compensation, asset size, central enterprise, gross profit margin of sale, ${ }^{4}$ compensation gap between executives and staffs, industry, and year. Among these control variables, executive

\footnotetext{
3 Managerial power is hard to measure. From the space dimension, managerial power mainly reflects the relationship between managers and big shareholders as well as the dominant positions managers have in corporate power structure. In accordance with China's reality, we believe that when top executives are in conspiracy with big shareholders and the managerial power embodies as big shareholder power, managerial power reaches it peak. Extant research (e.g., La Porta, Lopez-de-Silane, Shleifer and Vishny, 2002; Huang, 2006) shows that, in companies characterized by big relative control of big shareholders, separated control rights and cash-flow rights, and dispersed ownership structure, big shareholders have stronger motivation for tunneling behaviors and conspiracy with top executives. In addition to the impact of big shareholders, top executive's position in corporate power structure is also an important influencing factor for managerial power. For example, CEO duality indicates high managerial power in a listed company. From the time dimension, the most direct reflection of managerial power is a long-term tenure of top managers.

4 Following Chen et al.'s (2005) approach, we use gross sales margin to replace ROE, because all expenses including perquisite consumption should be excluded when calculating the numerator of ROE, resulting in a negative relationship between ROE and perquisite consumption.
} 
Table 1 Definition of Variables

\begin{tabular}{|c|c|c|}
\hline Variables & Definition & Specification \\
\hline$P C 1$ & $\begin{array}{l}\text { Type I } \\
\text { perquisite consumption }\end{array}$ & $\begin{array}{l}\text { Sum of the eight categories of perquisite consumption in } \\
\text { the subsidiary account titled "cash flow related to other } \\
\text { operating activities" in sampled listed companies' cash } \\
\text { flow statements / prime operating revenue }\end{array}$ \\
\hline$P C 2$ & $\begin{array}{l}\text { Type II } \\
\text { perquisite consumption }\end{array}$ & $\begin{array}{l}\text { Sum of the five categories of perquisite consumption in } \\
\text { the subsidiary account titled "cash flow related to other } \\
\text { operating activities" in sampled listed companies' cash } \\
\text { flow statements / prime operating revenue }\end{array}$ \\
\hline Dual & CEO duality & $\begin{array}{l}\text { It equals } 1 \text { if the president of a listed company also } \\
\text { concurrently holds the post of CEO, and } 0 \text { otherwise }\end{array}$ \\
\hline Disp & $\begin{array}{l}\text { Ownership structure } \\
\text { dispersion }\end{array}$ & $\begin{array}{l}\text { It equals } 1 \text { if the ratio of the percentage of the shares held } \\
\text { by the biggest shareholder to the sum of percentage of } \\
\text { shares held by the other top } 9 \text { shareholders is smaller } \\
\text { than } 1 \text {, and } 0 \text { otherwise }\end{array}$ \\
\hline Long & Long-term tenure & $\begin{array}{l}\text { It equals } 1 \text { if the president or the CEO of a sampled } \\
\text { company was in his/her current position before IPO } \\
\text { and still holds the position four years after IPO, and } 0 \\
\text { otherwise }\end{array}$ \\
\hline POWER 1 & $\begin{array}{l}\text { Dummy variable for } \\
\text { power }\end{array}$ & It equals 1 if Dual + Disp + Long $\geqslant 2$, and 0 otherwise \\
\hline POWER2 & $\begin{array}{l}\text { Integrated variable for } \\
\text { power }\end{array}$ & Dual + Disp + Long \\
\hline$P A Y$ & $\begin{array}{l}\text { Average compensation } \\
\text { for the top three highest } \\
\text { paid executives }\end{array}$ & $\begin{array}{l}\text { The logarithm of the average compensation of three } \\
\text { highest paid executives }\end{array}$ \\
\hline ASS & Asset size & The logarithm of the final total assets \\
\hline$S O E$ & $\begin{array}{l}\text { State-controlled } \\
\text { enterprise }\end{array}$ & $\begin{array}{l}\text { It equals } 1 \text { if the ultimate controller is the state, and } 0 \\
\text { otherwise }\end{array}$ \\
\hline CENTRA & Central enterprises & $\begin{array}{l}\text { It equals } 1 \text { if the ultimate controller is a central } \\
\text { government-controlled enterprise, and } 0 \text { otherwise }\end{array}$ \\
\hline MRS & Gross sales margin & Prime operating profit/prime operating revenue \\
\hline STAFFGAP & $\begin{array}{l}\text { Compensation gap } \\
\text { between top executives } \\
\text { and staff }\end{array}$ & $\begin{array}{l}\text { Average compensation of the three highest paid } \\
\text { executives / average wage of staff }\end{array}$ \\
\hline $\begin{array}{l}I N D_{m}(m= \\
1,2, \ldots, 20)\end{array}$ & $\begin{array}{l}20 \text { industry dummy } \\
\text { variables }\end{array}$ & $\begin{array}{l}\text { It equals } 1 \text { if a sampled company belongs to the focus } \\
\text { industry, and } 0 \text { otherwise. }\end{array}$ \\
\hline $\begin{array}{l}\operatorname{Year}_{n}(n= \\
02,03,04)\end{array}$ & 3 year dummy variables & $\begin{array}{l}\text { It equals } 1 \text { if a sampled company belongs to the focus } \\
\text { year }(2002,2003 \text { or } 2004) \text {, and } 0 \text { otherwise. }\end{array}$ \\
\hline$R O E$ & Return on equity & Net profits/ final shareholders' equity \\
\hline$R E T$ & $\begin{array}{l}\text { Annual stock market } \\
\text { returns }\end{array}$ & $\begin{array}{l}\prod_{i=1}^{12}\left(1+\operatorname{Ret}_{i}\right)-1 \quad\left(\operatorname{Ret}_{i} \text { stands for return on stock }\right. \\
\text { in month } i)\end{array}$ \\
\hline
\end{tabular}


compensation and perquisite consumption might form a certain substitutional or complementary relationship and the expected sign is uncertain. The central enterprise variable is added into the model to reflect current public concern about the excessively high monetary compensation of senior managers in central enterprises (with uncertain expected sign); the sign of enterprise rent (i.e., gross sales margin) is expected to be positive, indicating that there is a positive relationship between enterprise rent and perquisite consumption. Finally, we add into the model year variables to examine any possible impact of government rules (particularly the Regulations on Perquisite Compensation of Senior Managers in Central Enterprises in 2004) on perquisite consumption.

In Model (2), dependent variable is $R O E$ and explanatory variables include $P O W E R, P C$, and $S O E$. Considering that $P C_{i t}$ is the explained variable of Model (1), possible correlation might exist between $P C_{i t}$ and the interference item $\varepsilon_{i t}$ of Model (2), resulting in possible endogenous problem. Therefore, we adopt the generalized matrix method (GMM) for Model (2) and make $P C_{i t-1}$ the instrumental variable for $P C_{i t}$. According to $\mathrm{H} 1$, the coefficient for $P O W E R$ should not be significantly positive; according to $\mathrm{H} 2$, the coefficient for $S O E$ should not be significantly negative. In Model (2), the coefficient for PC can help to test the incentive effect of perquisite consumption. Controlled variables of Model (2) include asset size, executive compensation, and industry, among which the expected signs for asset size and industry are uncertain and executive compensation is expected to have positive sign.

\section{Empirical Test}

\subsection{Descriptive Statistics}

Table 2 presents the descriptive statistics of main variables in the models.

\subsection{Single Variable Analysis}

We divide sampled companies into managerial-power type $(P O W E R 1=1)$ and non-managerial-power type $(P O W E R 1=0)$. Mean value test is then conducted on their perquisite consumption and performance (including accounting performance $(R O E)$ and stock market performance (RET)), respectively. Similarly, we divide sampled companies into state-controlled ones $(S O E=1)$ and non-state-controlled samples $(S O E=0)$, and then carry out mean value test on their perquisite consumption and performance respectively, as shown in Table 3 below.

Table 3 demonstrates that managerial-power companies have significantly higher perquisite consumption than non-managerial-power companies. However, 
their performance is not significantly better than the latter. State-controlled listed companies have significantly lower perquisite consumption and better performance than non-state-controlled companies. These findings are consistent with $\mathrm{H} 1$ and $\mathrm{H} 2$.

Table 2 Descriptive Statistics of Main Variables

\begin{tabular}{lcccc|lcccc}
\hline Variable & Obs. & Mean & Median & $\begin{array}{c}\text { Standard } \\
\text { deviation }\end{array}$ & Variable & Obs. & Mean & Median & $\begin{array}{c}\text { Standard } \\
\text { deviation }\end{array}$ \\
\hline$P C 1$ & 1726 & 0.020 & 0.011 & 0.001 & SOE & 1723 & 0.760 & 1.00 & 0.010 \\
PC2 & 1589 & 0.013 & 0.007 & 0.001 & CENTRA & 1726 & 0.14 & 0.00 & 0.008 \\
POWER 1 & 1726 & 0.080 & 0.000 & 0.007 & MRS & 1726 & 0.234 & 0.205 & 0.004 \\
POWER2 & 1726 & 0.540 & 0.000 & 0.016 & STAFFGAP & 1726 & 5.33 & 3.91 & 0.114 \\
PAY & 1726 & 11.59 & 11.63 & 0.020 & ROE & 1726 & 0.019 & 0.065 & 0.012 \\
ASS & 1726 & 20.98 & 20.93 & 0.020 & RET & 1578 & -0.169 & -0.211 & 0.228 \\
\hline
\end{tabular}

Table 3 Single Variable Analysis of Perquisite Consumption and Firm Performance

\begin{tabular}{|c|c|c|c|c|c|c|c|c|}
\hline & $\begin{array}{l}\text { Managerial } \\
\text { Power }\end{array}$ & Obs. & Mean & $T$ value & $\begin{array}{l}\text { State } \\
\text { controlled }\end{array}$ & Obs. & Mean & Tvalue \\
\hline \multirow{2}{*}{$P C 1$} & 0 & 1580 & 0.020 & \multirow{2}{*}{$-2.42^{* *}$} & 0 & 414 & 0.029 & \multirow{2}{*}{$4.88^{* * *}$} \\
\hline & 1 & 146 & 0.027 & & 1 & 1309 & 0.018 & \\
\hline \multirow{2}{*}{$P C 2$} & 0 & 1454 & 0.013 & \multirow{2}{*}{$-3.49^{* * *}$} & 0 & 387 & 0.020 & \multirow{2}{*}{$5.86^{* * *}$} \\
\hline & 1 & 135 & 0.020 & & 1 & 1199 & 0.011 & \\
\hline \multirow{2}{*}{$R O E$} & 0 & 1580 & 0.019 & \multirow{2}{*}{0.013} & 0 & 414 & -0.057 & \multirow{2}{*}{$-2.15^{* *}$} \\
\hline & 1 & 146 & 0.018 & & 1 & 1309 & 0.043 & \\
\hline \multirow{2}{*}{$R E T$} & 0 & 1442 & -0.171 & \multirow{2}{*}{-1.14} & 0 & 364 & -0.200 & \multirow{2}{*}{$-2.96^{* * *}$} \\
\hline & 1 & 136 & -0.143 & & 1 & 1212 & -0.160 & \\
\hline
\end{tabular}

Note: $* * *, * *, *$ stand for significance levels of $1 \%, 5 \%$ and $10 \%$, respectively (two-tailed).

\subsection{Multiple Regression Analysis}

\subsubsection{Regression Analysis of Model (1)}

The regression analysis results of Model (1) are presented in Table 4.

Table 4 shows that: (1) When managerial power is a dummy variable or integrated variable, both kinds of perquisite consumption measurements are significantly and positively related to managerial power, regardless of managerial power as a dummy or integrated variable. The result is consistent with H1. (2) Perquisite consumption is significantly negatively related to SOE. In other words, non-state-controlled listed companies have significantly higher perquisite consumption than state-controlled listed companies-a result consistent with H2. (3) Perquisite consumption has a significantly positive relationship with monetary compensation. To find out the reason behind it, we divide sampled 
Table 4 Multiple Regression Results of Model (1)

\begin{tabular}{|c|c|c|c|c|c|}
\hline Variable & Expected sign & $P C 1$ & $P C 2$ & $P C 1$ & $P C 2$ \\
\hline Intercept & + & $\begin{array}{l}0.192^{* * *} \\
(8.232)\end{array}$ & $\begin{array}{l}0.128^{* * *} \\
(7.80)\end{array}$ & $\begin{array}{l}0.190^{* * *} \\
(8.148)\end{array}$ & $\begin{array}{l}0.126^{* * *} \\
(7.708)\end{array}$ \\
\hline POWER 1 & + & $\begin{array}{l}0.053^{* *} \\
(2.299)\end{array}$ & $\begin{array}{l}0.084^{* * *} \\
(3.535)\end{array}$ & & \\
\hline POWER2 & + & & & $\begin{array}{c}0.038^{*} \\
(1.624)\end{array}$ & $\begin{array}{l}0.071^{* * *} \\
(2.911)\end{array}$ \\
\hline$P A Y$ & ? & $\begin{array}{l}0.073^{* *} \\
(2.439)\end{array}$ & $\begin{array}{l}0.090^{* * *} \\
(2.910)\end{array}$ & $\begin{array}{l}0.074^{* *} \\
(2.462)\end{array}$ & $\begin{array}{l}0.089^{* * *} \\
(2.875)\end{array}$ \\
\hline$A S S$ & - & $\begin{array}{l}-0.218^{* * *} \\
(-8.899)\end{array}$ & $\begin{array}{l}-0.224^{* * *} \\
(-8.772)\end{array}$ & $\begin{array}{l}-0.217^{* * *} \\
(-8.858)\end{array}$ & $\begin{array}{l}-0.224^{* * *} \\
(-8.729)\end{array}$ \\
\hline$S O E$ & - & $\begin{array}{l}-0.082^{* * *} \\
(-3.323)\end{array}$ & $\begin{array}{l}-0.118^{* * *} \\
(-4.570)\end{array}$ & $\begin{array}{l}-0.079^{* * *} \\
(-3.184)\end{array}$ & $\begin{array}{l}-0.111^{* * *} \\
(-4.282)\end{array}$ \\
\hline CENTRA & $?$ & $\begin{array}{l}0.062^{* * *} \\
(2.578)\end{array}$ & $\begin{array}{l}0.051^{* *} \\
(2.019)\end{array}$ & $\begin{array}{l}0.060^{* *} \\
(2.518)\end{array}$ & $\begin{array}{c}0.048^{*} \\
(1.918)\end{array}$ \\
\hline$M R S$ & + & $\begin{array}{l}0.056^{* *} \\
(2.255)\end{array}$ & $\begin{array}{c}0.040 \\
(1.556)\end{array}$ & $\begin{array}{l}0.057^{* *} \\
(2.278)\end{array}$ & $\begin{array}{c}0.041 \\
(1.581)\end{array}$ \\
\hline STAFFGAP & ? & $\begin{array}{c}-0.016 \\
(-0.615)\end{array}$ & $\begin{array}{c}-0.036 \\
(-1.300)\end{array}$ & $\begin{array}{c}-0.018 \\
(-0.690)\end{array}$ & $\begin{array}{l}-0.039 \\
(-1.412)\end{array}$ \\
\hline $\begin{array}{c}I N D_{m}(m=1 \\
2, \ldots, 20)\end{array}$ & ? & Control & Control & Control & Control \\
\hline $\begin{array}{c}\operatorname{Year}_{n}(n=02 \\
03,04)\end{array}$ & ? & Control & Control & Control & Control \\
\hline Adj. $R^{2}$ & & 0.139 & 0.142 & 0.137 & 0.140 \\
\hline Obs. & & 1723 & 1586 & 1723 & 1586 \\
\hline
\end{tabular}

Note: Numbers in brackets are the $T$ values modified with White's heteroskedasticity test. ***, **, * stand for significance levels of $1 \%, 5 \%$ and $10 \%$ (two-tailed), respectively.

companies into state-controlled and non-state-controlled ones and redo the model test (exclude the $S O E$ variable, of course). The results show that perquisite consumption has a significant and positive relationship with monetary compensation in non-state-controlled sample, while in state-controlled sample, the relationship ceases to be significant (though still positive). Other findings include that perquisite consumption has a significant and negative relationship with asset size; there is no significant fluctuation in perquisite consumption in different years, even in 2004 when the Regulations on Perquisite Compensation of Senior Managers in Central Enterprises was issued; perquisite consumption has a significant and positive relationship with enterprise rent (namely gross sales margin) and the relationship is much more significant in central enterprises than in ordinary state-controlled companies.

\subsubsection{Regression Analysis of Model (2)}

To find any possible endogenous problems incurred by adding $P C_{i t}$ into Model (2), we test the $\chi^{2}$ (1) statistical data with Durbin-Wu-Hausman (DWH) method. 
The result shows that $\chi^{2}(1)$ value is 27.15 at the 0.01 significance level, indicating the existence of certain endogenous problem. It is therefore necessary to employ GMM approach in our analysis.

When using the GMM method to conduct regression analysis on Model (2), we divide sampled companies into three subgroups, namely all sampled companies, state-controlled and non-state-controlled samples. As both POWER and $P C$ have two kinds of measuring indices, there are four regression results for each of the three sub-sample groups.

The POWER coefficient for all samples is insignificant, showing that managerial power can bring forth higher perquisite consumption, but not necessarily better performance, which is consistent with $\mathrm{H} 1$.

The coefficient for $S O E$ is significantly positive, indicating state-controlled companies have significantly better performance than non-state-controlled companies, a finding not conflictive to H2. In addition, we find that the coefficient for $P C$ is significantly negative, suggesting that perquisite consumption has a negative, rather than positive impact on firm performance. However, senior managers' compensation is significantly and positively related to firm performance, showing that monetary compensation is still an effective incentive for managers.

The regression results of state-controlled and non-state-controlled samples are consistent with that of all samples to a large extent. The only difference lies in the coefficient of POWER: The coefficient for POWER is negative and insignificant for state-controlled samples but positive and not significant for non-state-controlled samples, suggesting that managerial power can bring forth significant damage to state-controlled companies. This result, however, does not conflict with the above conclusions that the level of perquisite consumption in private companies is higher than that of in state-controlled companies, which in turn leads to a negative impact on performance of private companies. As demonstrated in Table 6, the managerial power in non-state-controlled listed companies is significantly higher than that of in state-controlled listed companies.

As above, the test of Model (1) illustrates that managerial power will significantly raise perquisite consumption and the test of Model (2) demonstrates that perquisite consumption will significantly lower firm performance. Table 6 shows that managers in non-state-controlled listed companies have a significantly higher managerial power than their peers in state-controlled listed companies. All these results support the logic reasoning of this paper: Compared with state-controlled listed companies, the increase in managerial power in non-state-controlled companies will lead to higher perquisite consumption, and most probably worsen firm performance. Above analysis also reveals a significant and negative impact of managerial power in firm performance for 


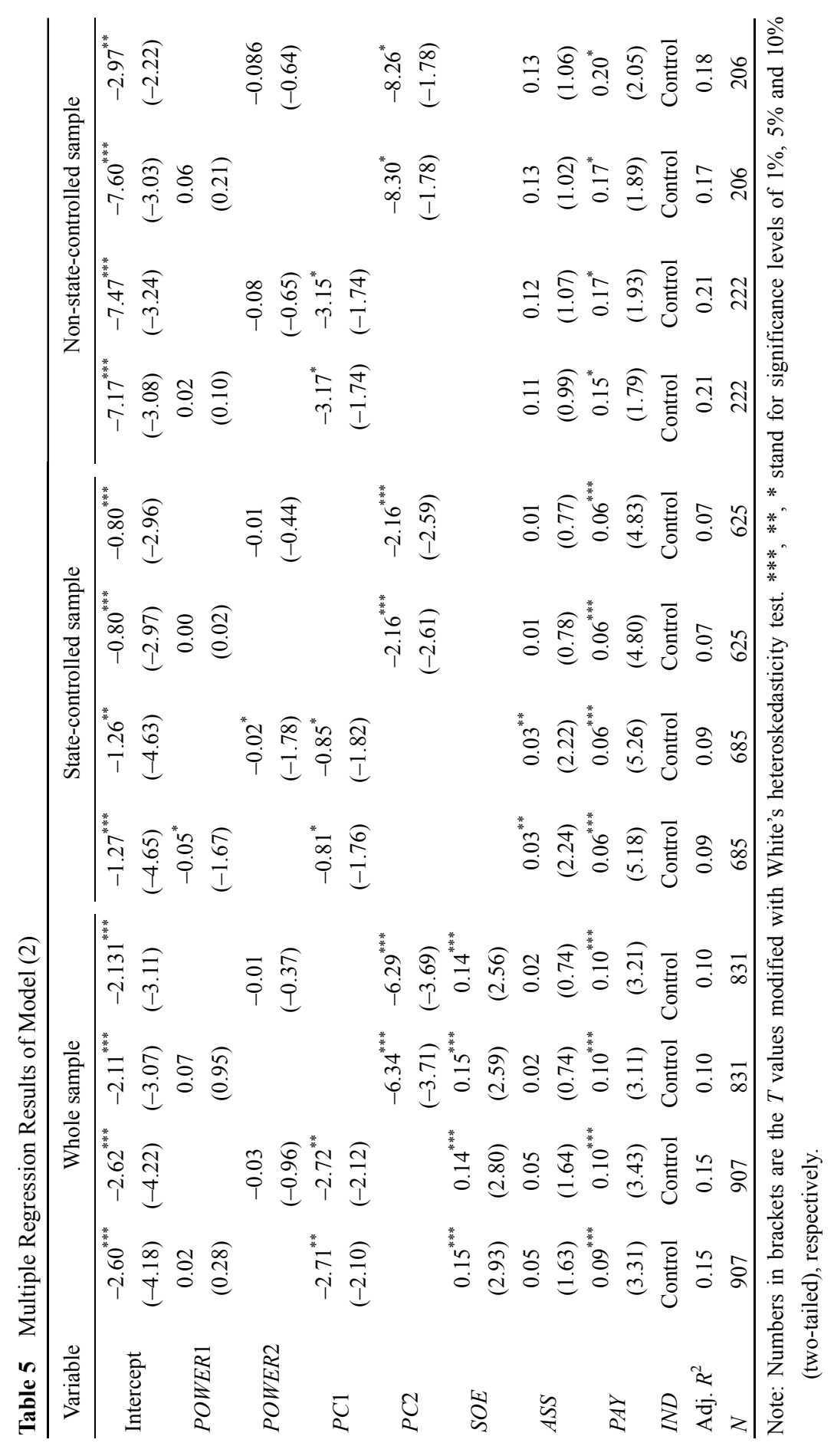


Table 6 Comparison of Managerial Power in State-Controlled and Non-State-Controlled Companies

\begin{tabular}{cclcc}
\hline & State-controlled & Obs. & Mean & $T$ value \\
\hline \multirow{2}{*}{ POWER 1} & 0 & 414 & 0.12 & $2.58^{* * *}$ \\
& 1 & 1309 & 0.07 & \\
POWER 2 & 0 & 414 & 0.73 & $6.95^{* * *}$ \\
\hline
\end{tabular}

state-controlled enterprises. One possible explanation might be that senior managers in SOEs might influence firm performance via other means or approaches rather than solely dependent on perquisite consumption. For example, although have smaller managerial power compared with their peers in non-state-controlled companies, there are more cases of ill-considered investment in SOEs than in non-SOEs.

\subsection{Robustness Check}

Two different measurement methods of perquisite consumption were used to test the robustness of our conclusions. One is similar to the method adopted by Li et al.'s (2005) calculation of the ratio of administration expense to prime operating revenue, but we excluded non-perquisite consumption items such as executive compensation, provision for bad debts and provision for decline in value of inventory, amortization of intangible assets. The other method is to calculate the ratio of the sum of administration expenses and operating expenses to prime operating revenue in order to reflect the level of perquisite consumption. Likewise, non-perquisite consumption items were eliminated. Consistent conclusions with the above analyses were achieved, namely managerial power is significantly and positively related to perquisite consumption, and perquisite consumption is significantly and negatively related to firm performance. We also used CEO duality, ownership structure dispersion, and long-term tenure of top executives as indicators of managerial power to re-test the hypotheses. The results show that, except for long-term tenure, both of the other two indicators significantly improve perquisite consumption and lower firm performance. In addition, with the new indicators, the difference between state-controlled companies and non-state-controlled companies remain more or less unchanged.

In addition, in the original models, we used the average compensation of the three highest paid executives as the variable for executive compensation and the compensation gap between executives and staff. Similar conclusions were obtained when we used the average compensation of the three highest paid board members to replace the executive compensation. The above main conclusions 
remained unchanged even when we used RET, ROA to replace ROE in Model (2) and added new control variables such as asset-debt ratio, region, year, etc.

\section{Conclusion and Limitation}

In China's transitional economy, due to the lack of effective contract management mechanisms and developed manager market, excessive perquisite consumption might be a reduction of the gap between the compensation managers actually received and their market value and therefore provides a certain incentive to managers, or a tunneling of the interests of listed companies or other stakeholders. Based on the perquisite consumption data of Chinese listed companies during 2001-2004 disclosed in sampled companies' annual reports, this paper studies the relationship among managerial power, perquisite consumption and the efficiency of property right system. We find that, managerial power is significantly and positively related to perquisite consumption, but not significantly related to firm performance; perquisite consumption is negatively related to firm performance. Managers in non-state-controlled listed companies tend to have greater power, higher perquisite consumption, but poorer performance. Our findings suggest that managerial power is likely to be used as a rent-seeking instrument for top executives. We therefore should pay more attention to governance over managerial power and excessive perquisite consumption. The findings in this article further enrich our understanding of the relationship between managerial power and compensation incentives.

The main limitation of this paper is that there might be selective bias in selecting sampled companies which disclosed their perquisite consumption data. This bias might negatively influence the applicability of our conclusions. In addition, we did not take into consideration other possible approaches top executives might adopt to influence enterprise performance. ${ }^{5}$ Finally, more attention should be paid to the origin of managerial power, its measurement, difference in perquisite consumption items between state-controlled and non-state-controlled listed companies, and specific ways top executives adopt to encroach the interests of other stakeholders.

Acknowledgements This work is supported by the National Natural Science Foundation of China (No.70532003, 70802062, and 70802024). The authors thank Yujun Lian and Guojian Zheng for their constructive comments.

\footnotetext{
5 As the overall impact of managerial power on firm performance is not significant in Model (2), there must exist other ways top executives might adopt to enhance firm performance.
} 


\section{References}

Alchian A, Demsetz H (1972). Production, information costs and economic organization. American Economic Review, 12: 780-781

Bebchuk L, Fried J, Walker D (2002). Managerial power and rent extraction in the design of executive compensation. University of Chicago Law Review, 69: 751-846

Bebchuk L, Fried J (2003). Executive compensation as an agency problem. Journal of Economics Perspective, 17(3): 71-92

Bebchuk L, Fried J (2004). Pay without Performance: The Unfulfilled Promise of Executive Compensation. Cambridge: Harvard University Press

Cheng S (2005). Managerial entrenchment and loss-shielding in executive compensation. Working Paper, University of Michigan

Core J, Holthausen R, Larker D (1999). Corporate governance, chief executive compensation and firm performance. Journal of Financial Economics, 51: 371-406

Hambrick D C, Finkelstein S (1995). The effects of ownership structure on conditions at the top: The case of CEO pay rises. Strategic Management Journal, 16: 175-193

Hu A, Kumar P (2004). Managerial entrenchment and payout policy. Journal of Financial and Quantitative Analysis, 39(4): 759-790

Jensen M C, Meckling W H (1976). Theory of the firm: Managerial behavior, agency costs and ownership structure. Journal of Financial Economics, 3: 305-360

La Porta R, Lopez-de-Silanes F, Shleifer A, Vishny R W (2002). Investor protection and corporate valuation. Journal of Finance, (June): 1147-1170

Main B (1993). Pay in the boardroom practices and procedures. Personnel Review, 22: 3-14

Main G, O'Reily C, Wade J (1995). The CEO, the board of directors and executive compensation: Economic and psychological perspectives. Industrial and Corporate Change, 11: $602-628$

Rajan R, Wulf J (2006). Are perks purely managerial excess? Journal of Financial Economics, 79: $1-33$

$\mathrm{Xu} \mathrm{L}$ (2004). Large shareholder type, corporate governance and corporate performance: Evidence from Chinese listed companies. Doctoral Dissertation, the Hong Kong Polytechnic University

Yermack D (2005). Flights of fancy: Corporate jets, CEO perquisites, and inferior shareholder returns. Working Paper, www.ssrn.com

陈冬华, 陈信元, 万华林 (Chen Donghua, Chen Xinyuan, Wan Hualin) (2005). 国有企业中 的薪酬管制与在职消费 (Compensation supervision and perquisite consumption in state-owned companies). 经济研究, (2): 92-101

陈工孟 (Chen Gongmeng) (1997). 现代企业代理问题与国有企业改革 (Modern enterprises' agency problem and SOE reform). 经济研究, (10): 43-46

费方域 (Fei Fangyu) (1996). 控制内部人控制 (Control insider control). 经济研究，(6): 31-39

何浚 (He Jun) (1998). 上市公司治理结构的实证分析 (Empirical analysis of governance structure of listed companies). 经济研究, (5): 50-57

黄群慧 (Huang Qunhui) (2000). 控制权作为企业家激励约束因素: 理论分析与现实解释 意义 (Control power as an constraint factor of entrepreneur incentive: Theoretical analysis and practical explanatory significance). 经济研究, (1): 41-47

黄志忠 (Huang Zhizhong) (2006). 股权比例、大股东掏空策略与全流通 (Equity ratio, large shareholders' tunneling tactics and full circulation). 南开管理评论, (9): 58-65

李增泉, 孙铮, 刘风委 (Li Zengquan, Sun Zheng, Liu Fengwei) (2005). 企业绩效与薪酬契 
约一一基于最优契约论的解释与经验证据 (Firm performance and compensation contract: Based on the optimal contracting approach and empirical evidence). 东亚会计与经济杂志 年会论文集

李增泉, 孙铮, 王志伟 (Li Zengquan, Sun Zheng, Wang Zhiwei) (2004). 掏空与所有权安 排一一来自我国上市公司大股东资金占用的经验证据 (Tunneling and property right arrangement: Empirical research of large shareholders' occupation of capital in listed companies). 会计研究, (8): 102-110

刘峰, 贺建刚, 魏明海 (Liu Feng, He Jiangang, Wei Minghai) (2004). 控制权、业绩与利 益输送一一基于五粮液的案例研究 (Control power, performance and benefit tunneling: Empirical research based on Wuliangye). 管理世界, (8): 102-110

刘伟, 李绍荣 (Liu Wei, Li Shaorong) (2003). 所有制变化与经济增长和要素效率提升 (Change of ownership system, economic growth and promotion of element efficiency). 经 济研究, (8): 36-45

卢锐 (Lu Rui) (2007). 管理层权力、薪酬差距与绩效 (Managerial power, compensation gap and performance). 南方经济, (7): 60-70

苏启林，朱文 (Su Qilin, Zhu Wen) (2003). 上市公司家族控制与企业价值 (Family control of listed companies and corporate value). 经济研究, (8): 36-45

王克敏, 王志超 (Wang Kemin, Wang Zhichao) (2007). 高管控制权、报酬与盈余管理 (Executive control power, compensation and earnings management). 管理世界, (7): $111-119$

魏刚 (Wei Gang) (2000). 高级管理层激励与上市公司经营业绩 (Senior executives' incentives and listed companies' performance). 经济研究, (3): 31-37

夏冬林, 李晓强 (Xia Donglin, Li Xiaoqiang) (2004). 在职消费与公司治理机制 (Perquisite consumption and corporate governance mechanism). 中国会计学会第六届理事会第二次 会议暨 2004 年学术年会论文集, (7): 361-369

杨贺, 柯大钢, 马春爱 (Yang He, Ke Dagang, Ma Chun'ai) (2005). 经理人控制对高级管 理人员报酬制定影响的实证研究 (Empirical research of the influence manager control has on executive compensation). 管理科学, (3): 28-32

杨兴君, 宗长玉, 江艺 (Yang Xingjun, Zong Changyu, Jiang Yi) (2005). 民营企业控制多 家上市公司实证研究 (Empirical research of private enterprise controlling several listed companies). 深圳证券交易所研究报告

张必武, 石金涛 (Zhang Biwu, Shi Jintao) (2005). 董事会特征、高管报酬与薪酬业绩敏感 性 (Characteristic of board of directors, executive compensation and the sensitivity between compensation and performance). 管理科学, (4): 32-39

张维迎 (Zhang Weiying) (1998). 控制权丧失的不可弥补性与国有企业兼并中的产权障碍 (The irreparableness of lost control right and property right obstacles in mergers of state-owned companies). 经济研究, (7): 3-14

周其仁 (Zhou Qiren) (1997). 控制权回报与企业家控制的企业一一公有制经济中企业家 人力资本产权的案例研究 (Control power benefits and entrepreneur-controlled companies: Empirical research on property right of entrepreneurs' human capital of public sector of the economy). 经济研究, (5): 31-42 